\title{
GENETIC TREND FOR MILK PRODUCTION AND LONGEVITY TRAITS OF EGYPTIAN BUFFALO
}

\author{
Dalia K.A. EL-Hedainy ${ }^{1 *}$ Kholood A.K. Elbanhawy ${ }^{1}$, A.M.S. Amin' ${ }^{2}$, M.M.I. Salem ${ }^{1}$, M.H. \\ Hammoud ${ }^{1}$, and A.S.A. El-Barbary ${ }^{1}$
}

1- Animal Production Department, Faculty of Agriculture (El-Shatby), Alexandria University, Alexandria 22545, Egypt, 2- Animal Production Research Institute, Agricultural Research Center, Dooki, Giza, 12619, Egypt, "Corresponding author, Tel.:002 03 5900846; fax: 00203 5922780., e-mail address: dheddany@yahoo.com, ORCID NO.:0000-0002-0549-106x

Received: 28 /11 / $2019 \quad$ Accepted: 29/07/2020

\section{SUMMARY}

Data used in this study comprised 1792 records for 1126 buffalo female born from 1980 to 2013, daughters of 101 sires and 896 dams from four buffalo herds (El-Nattafe el gadid, El-Nattafe el kadim, Mahalet mousa and El-gmeza) that belong to the Animal Production Research Institute (APRI), Ministry of Agriculture and Land Reclamation, Egypt. The objective was estimate the heritability and genetic trend of some milk production and longevity traits of Egyptian buffaloes that we know precisely which traits can be improved using genetic improvement. The studied traits were milk production traits (total milk yield, 305- days milk yield and lactation period) and longevity traits (total milk yield during the productive life, productive life and number of lactations). The least squares means of the milk production traits were $1176.53,1172.61 \mathrm{~kg}$ and 202 days of the total milk yield, 305-days milk yield and lactation period, respectively. The least squares means of longevity traits were $6905.04 \mathrm{~kg}, 952$ days and 5.6 lactation of total milk yield during productive life, productive life and number of lactations, respectively.

The heritability estimates for the milk production traits were 0.498 of the total milk yield, 0.492 of 305-days milk yield and 0.189 for lactation period. The heritability estimates for longevity traits were 0.497 of total milk yield during productive life, 0.498 of productive life and 0.069 of number of lactations. The estimated breeding values for all traits varied widely. The genetic trends of animal and dam breeding values were significant for all studied. This confirms that the genetic improvement of these traits leads to increased milk production.

\section{Keywords: heritability, genetic trend, Egyptian buffalo}

\section{INTRODUCTION}

The domestic water buffalo (Bubalus bubalis) contributes a significant share of global milk production and the major milk producing animal in several countries like Egypt. Also, buffaloes are multi-purpose mainly kept for milk, meat and sometimes draft power. In Egypt buffalo population is about 3.7 million head, approximately $47 \%$ from the previous number produce milk (Arab Organization for Agricultural Development, 2017). River buffaloes usually produce between 1.500 and 4.500 liters of milk per lactation. They have a significantly longer productive life than cows in general (Peeva and Ilieva, 2007), providing calves and milk until they are up to 20 years of age. The many factors that constrain commercial buffalo milk farm include animals' late age at first calving, the seasonality of oestrus, and the long calving interval and dry period (Shah, 2007).

In recent decades, breeding programs especially in Bulgaria, China, Egypt, India and Pakistan have attempted to improve the milk yield of river buffalo. To improve the production traits of buffaloes, variance components, genetic and phenotypic parameters must be estimated. Accurate estimates of these traits cannot be calculated without adjusting of non-genetic factors that significantly influencing these traits.
Genetic trend is defined as a change in performance per unit of time due to change in the mean of breeding value, while phenotypic trend is a change in production per unit of time (Hebert and Bhatnaga, 1988). The trends are indicative of the progress or decline that has been attained using the breeding strategy in place (Ojango and Pollott, 2001).In general, favorable phenotypic and genetic trends can be achieved if the environment and breeding management are improved. There is a need to continuously evaluate the genetic and phenotypic parameters and trends in dairy cattle and buffalo to monitor whether the parameters and trends are desirable for each trait (Amimo et al., 2007).

The present study were conducted to study the effect of environmental factors on milk production, longevity traits and estimate the heritability, breeding values and genetic trends of the studied traits of the Egyptian buffalo in order to know the productive traits that can recommended to be improved using genetic improvement.

\section{MATERIALS AND METHODS}

\section{Data:}

Data were collected from four buffalo herds (ElNattafe el gadid, El-Nattafe el kadim, Mahalet mousa and El-gmeza)belonging to the Animal Production Research Institute (APRI), Ministry of Agriculture 
and Land Reclamation, Egypt. The data consisted of 1126 buffalo female born from 1980 to 2013, daughters of 101 sires and 896 dams.

\section{Herd management:}

Animals were fed Berseem, rice straw and concentrate. Amount of ration given to the animals was determined according to body weight and amount of milk production. The feed was offered twice daily and water was available all the time. The hand- milking of buffalo cows were twice daily at 7 am. and $4 \mathrm{pm}$. during the lactation period. The mating system was naturally. The first insemination for heifers was at 24 month of age $(330 \mathrm{~kg}$ of body live weight). The dry period was two months before calving.

\section{Studied traits:}

\section{Milk production traits:}

a. Total milk yield calculated by cumulated amount of milk yield in kilograms of a cow during lactation period.

b. 305-day milk yield calculated by the following equation:

305-day milk yield $=$ The actual amount of milk $\times 305$ Lactation period

(Khan and Chaudhry, 2001).

c. Lactation period was calculated as the difference between dry off date and calving data.

\section{Productive life traits:}

a. Total milk yield during the productive life including cumulated total milk yield produced through productive life of buffalo cow.

b. Productive life calculated as the period from first calving date to disposal date from farm.

c. Number of lactations, calculated as total number of completed lactations during productive life of buffalo cow.

\section{Statistical analysis:}

Preliminary analysis of data indicated that the interactions between combination from each of

Table 1. Least square means (LSM) \pm standard deviation (SD) and coefficient of variation (CV) of the studied traits

\begin{tabular}{lcc}
\hline Traits & LSM \pm SD & CV\% \\
\hline Milk production traits & & 33 \\
Lactation period (days) & $202.12 \pm 66.5$ & 45 \\
Total milk yield (kg) & $1176.53 \pm 350.66$ & 44 \\
305-day milk yield (kg) & $1172.61 \pm 519.87$ & \\
Longevity traits & & 45 \\
Number of lactations (no.) & $5.64 \pm 2.55$ & 53 \\
Productive life (days) & $952.95 \pm 504.59$ & 55 \\
Total milk yield during the productive life (kg) & $6905.04 \pm 3831.88$ & \\
\hline
\end{tabular}

\section{Environmental factors:}

Means squares of the factors affecting the milk production and longevity traits are presented in Table (2). The effect of herd on all traits studied was significant. While the effect of other factors was not significant, except year of calving effect on lactation period and all longevity traits expect total milk yield season of first calving year of first calving and herds could be not calculated due to missed cells of data. Least squares analysis using GLM procedure (SAS 2010) was used to test the significant of the fixed effects including season of first calving (four seasons), year of first calving (29 year) and herd (four herds) using the following statistical model:

Where,

$$
\mathrm{Y}_{\mathrm{ijkl}}=\mu+\mathrm{S}_{\mathrm{i}}+\mathrm{T}_{\mathrm{j}}+\mathrm{H}_{\mathrm{k}}+\mathrm{e}_{\mathrm{ijkl}}
$$

$\mathrm{Y}_{\mathrm{ijkl}}$ : the observations of the studied traits.

$\mu$ : overall mean specific to each trait;

$\mathrm{S}_{\mathrm{i}}$ : the fixed effect of $i^{\text {th }}$ season of first calving;

$T_{j}$ : the fixed effect of $j^{\text {th }}$ year of first calving;

$\mathrm{H}_{\mathrm{k}}$ : the fixed effect of $\mathrm{k}^{\text {th }}$ of herd, and

$\mathrm{e}_{\mathrm{ijkl}}$ : random residual assumed to be independent normally distributed with mean zero and variance.

Variance components and the genetic parameters for the studied traits were estimated by WOMBAT program (Meyer, 2005).

The univariate animal model was as follows:

$$
\mathbf{y}=\mathbf{X b}+\mathbf{Z a}+\mathbf{e}
$$

Where $y$ is a vector of observations, $\boldsymbol{b}$ is the vector of fixed effects with incidence matrix X, $\boldsymbol{a}$ is the vector of random animal effect with incidence matrix $\mathrm{Z}$ and $\boldsymbol{e}$ is the vector of random residual effect. The vector of additive (animal) effect (a) was assumed to be $\mathrm{N} \sim\left(0, A \sigma^{2}\right)$, where $\mathrm{A}$ is the numerator relationship matrix among animals in the pedigree file and $\sigma^{2}$ is the additive genetic variance. The vector of residual (environmental) effects (e) was assumed to be $\mathrm{N} \sim(0$, $I \sigma_{e}^{2}$ ), where I being the identity matrix, and $\sigma_{e}^{2}$ is the environmental variance.

\section{RESULTS AND DISCUSSION}

Least squares means of the studied traits are presented in table (1). From this table, all traits were characterized by high coefficients of variation, that reflecting the wide variation among the individuals performance. during the longevity life. The effect of environmental factors on longevity traits was significant in number of lactation and longevity life with herd factor, while the year of calving affect significantly with all longevity traits. But season of calving is not significant on all longevity traits. 
These previous results are in agreement with that found by Aziz et al. (2001) and Cady et al. (1983) they found that the year of calving and herd had a significant effect on lactation period. Also, Aziz et al. (2001) and Thiruvenkadan et al. (2015) reported that season of calving had no significant effect on lactation period. The longevity traits results of the study were agreement with that recorded by Bashir et al. (2007) who found significant effect of herd on longevity traits in Nili-Ravi buffalo. The same results reported by Galeazzi et al. (2010) in Murra buffalo in Brazil. In addition to, season of calving effect significantly one productive live and insignificant effect on life time milk yield and herd life (Bashir et $a l ., 2007)$ that agreement with the results of the present study. Also, Jakhar et al, (2016) found insignificant effect of season on total milk yield. Khattab et al. (2017) proved that the year of calving had a significant effect on longevity traits. Moreever, the significant effect of the year of first calving on longevity traits reported by (Bashir et al. ,2007; Galeazzi et al. ,2010 and Jakhar et al. , 2016), that what agreement with the result reported in this study. And the significant effect of the year on longevity traits may be due to different nutrition and management system at different periods and phenotypic trend (Khattab et al., 2017).

Table 2. Mean squares of the factors affecting the milk production and longevity traits

\begin{tabular}{|c|c|c|c|c|c|c|}
\hline \multirow{3}{*}{$\begin{array}{c}\text { Source of } \\
\text { variation }\end{array}$} & \multicolumn{6}{|c|}{ Mean squares } \\
\hline & \multicolumn{3}{|c|}{ Milk production traits } & \multicolumn{3}{|c|}{ Production Life } \\
\hline & $\begin{array}{l}\text { Lactation } \\
\text { period } \\
\text { (days) }\end{array}$ & $\begin{array}{l}\text { Total Milk } \\
\text { Yield } \\
(\mathrm{Kg})\end{array}$ & $\begin{array}{c}\text { 305-day Milk } \\
\text { yield } \\
(\mathrm{Kg})\end{array}$ & $\begin{array}{l}\text { Number of } \\
\text { lactation } \\
\text { (No.) }\end{array}$ & $\begin{array}{c}\text { Productive } \\
\text { life } \\
\text { (days) }\end{array}$ & $\begin{array}{l}\text { Total yield during } \\
\text { the productive life } \\
(\mathrm{Kg})\end{array}$ \\
\hline Herd & $28987^{* *}$ & $818912^{*}$ & $805456^{*}$ & $15^{*}$ & $1220595^{* *}$ & 16518982 \\
\hline $\begin{array}{l}\text { Year of first } \\
\text { calving }\end{array}$ & $14518^{*}$ & 335241 & 322654 & $99^{* *}$ & $4116273^{* *}$ & $12253182^{* *}$ \\
\hline Season of first & 2544 & 201582 & 303166 & 14 & 378611 & 10719384 \\
\hline Error & 6194 & 116179 & 747365 & 5 & 190757 & 1328365 \\
\hline
\end{tabular}

${ }^{*}$ Significant at $\mathrm{P}<0.05 \quad{ }^{* *}$ Significant at $\mathrm{P}<0.01$

\section{Heritability estimates :}

Table (3) show the heritability estimates for the studied traits. The heritability estimate of the total milk yield (0.498), 305- day milk yield (0.492), longevity life $(0.498)$ and total milk yield during the productive life $(0.497)$ were the highest estimates than the other study traits. Perhaps these higher results of heritability are due to increase the genetic variation, which causes individuals to show more phenotypic variance. But the heritability of the lactation period and numbers of lactations were lower than the other studied traits, they were 0.189 and 0.069 , respectively. Which indicates that, heredity has a reasonable effect on the improvement of these traits, and it is possible to genetically improve these traits while improving the environmental conditions that affect those traits from the other traits that genetics decrease, and the most effective in improving them, improving the environmental conditions affecting them only.

From the literature the heritability estimates of lactation period was 0.189 it was higher than the estimates by Tonhati et al. (2000) that was 0.01 , Morammazi et al. (2007) 0.045, Khattab et al. (2017) 0.13 and El- Bramony et al. (2014) 0.06. The heritability estimates total milk yield was 0.492 it was higher than the estimated by Zadeh et al (2016) 0.46, Tonhati et al. (2000) 0.38, Pareek et al. (2014) 0.29, Morammazi et al. (2007) 0.077 and ElBramony et al. (2014) 0.11 . The heritability estimates of adjusted milk yield (0.492) is higher than those recorded by Pareek and Narang (2014) it was $0.19+$ 0.08 and Khan et al. (2007) it was $0.243+0.05$.

Table 3. Heritability $\left(h^{2}\right)$ estimates and their standard error (SE) for the studied traits

\begin{tabular}{lcc}
\hline traits & $\mathbf{h}^{2}$ & SE \\
\hline Milk production traits & & 0.064 \\
Lactation period (days) & 0.189 & 0.007 \\
Total milk yield (kg) & 0.498 & 0.018 \\
305-day milk yield (kg) & 0.492 & 0.037 \\
Productive life traits & & 0.006 \\
Number of lactations (no.) & 0.069 & 0.007 \\
Productive life (days) & 0.498 & 0.497 \\
Total milk yield during the productive life (kg) & & \\
\hline
\end{tabular}

\section{Estimates of breeding values:}

The breeding values and genetic trend are presented in Table 4, 5 and Figure 1, respectively. The estimates of breeding values of the studied traits were varied widely. Also, the genetic trend of animal and dam breeding value were insignificant for all study traits, which indicated that the selection programs weren't applied for these herds. Bashir et al. (2007) and Ahmed (2016) found positive genetic trend for longevity and milk traits in Nili- Ravi buffalo. In this study, the animal genetic trend was positive for all traits were studied. 
Table 4. Breeding values of animals, sire and dam of studied traits in Egyptian buffalo

\begin{tabular}{|c|c|c|c|c|c|c|}
\hline \multirow[t]{2}{*}{ Traits } & \multicolumn{2}{|c|}{ Buffalo } & \multicolumn{2}{|c|}{ Sire } & \multicolumn{2}{|c|}{ Dam } \\
\hline & Min. & Max. & Min. & Max. & Min. & Max. \\
\hline \multicolumn{7}{|l|}{ Milk production traits } \\
\hline Lactation period (days) & -166 & 269 & -14 & 25 & -65 & 108 \\
\hline Total milk yield $(\mathrm{kg})$ & -881 & 1904 & -146 & 269 & -489 & 940 \\
\hline 305-day milk yield $(\mathrm{kg})$ & -842 & 1417 & -147 & 257 & -503 & 951 \\
\hline \multicolumn{7}{|l|}{ Longevity traits } \\
\hline Number of lactations (no.) & -3.23 & 3 & -0.440 & 0.489 & -0.532 & 0.922 \\
\hline Productive life (days) & -649 & 5920 & -68 & 82 & -331 & 501 \\
\hline $\begin{array}{l}\text { Total milk yield during the } \\
\text { productive life }(\mathrm{kg})\end{array}$ & -5205 & 6417 & -574 & 479 & -1739 & 1861 \\
\hline
\end{tabular}

Table 5. Regression coefficients and Standard error of estimated breeding values of buffalo and dam on year of calving for studied traits

\begin{tabular}{lcccc}
\hline Traits & \multicolumn{2}{c}{ Buffalo } & \multicolumn{2}{c}{ Dam } \\
\cline { 2 - 5 } & $\begin{array}{c}\text { Regression } \\
\text { Coefficients }\end{array}$ & $\begin{array}{c}\text { Standard } \\
\text { error }\end{array}$ & $\begin{array}{c}\text { Regression } \\
\text { Coefficients }\end{array}$ & $\begin{array}{c}\text { Standard } \\
\text { error }\end{array}$ \\
\hline Milk production traits & & & & \\
Lactation period (days) & 0.645 & 0.516 & 0.267 & 0.225 \\
Total milk yield (kg) & 3.332 & 4.031 & 0.375 & 1.705 \\
305-day milk yield (kg) & 3.784 & 3.949 & -0.464 & 1.594 \\
Longevity traits & & & & \\
Number of lactations (no.) & 0.012 & 0.012 & -0.002 & 0.002 \\
Productive life (days) & 3.935 & 3.567 & -1.581 & 1.527 \\
Total milk yield during the productive life (kg) & 19.511 & 23.921 & -5.202 & 6.995 \\
\hline
\end{tabular}

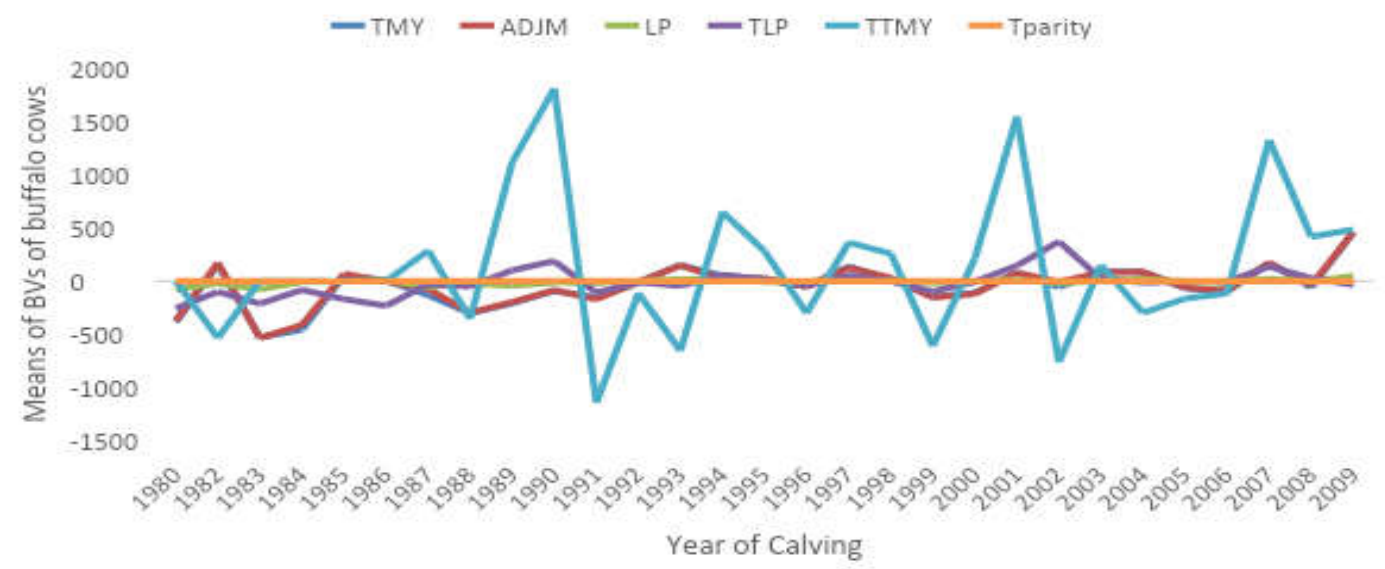

(a)

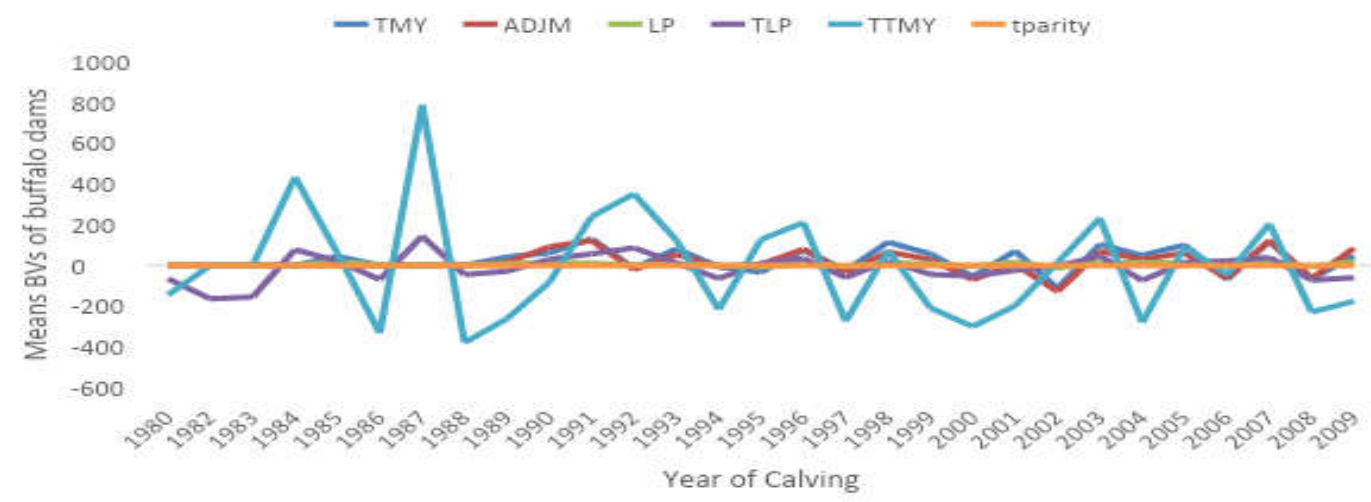

(b) 


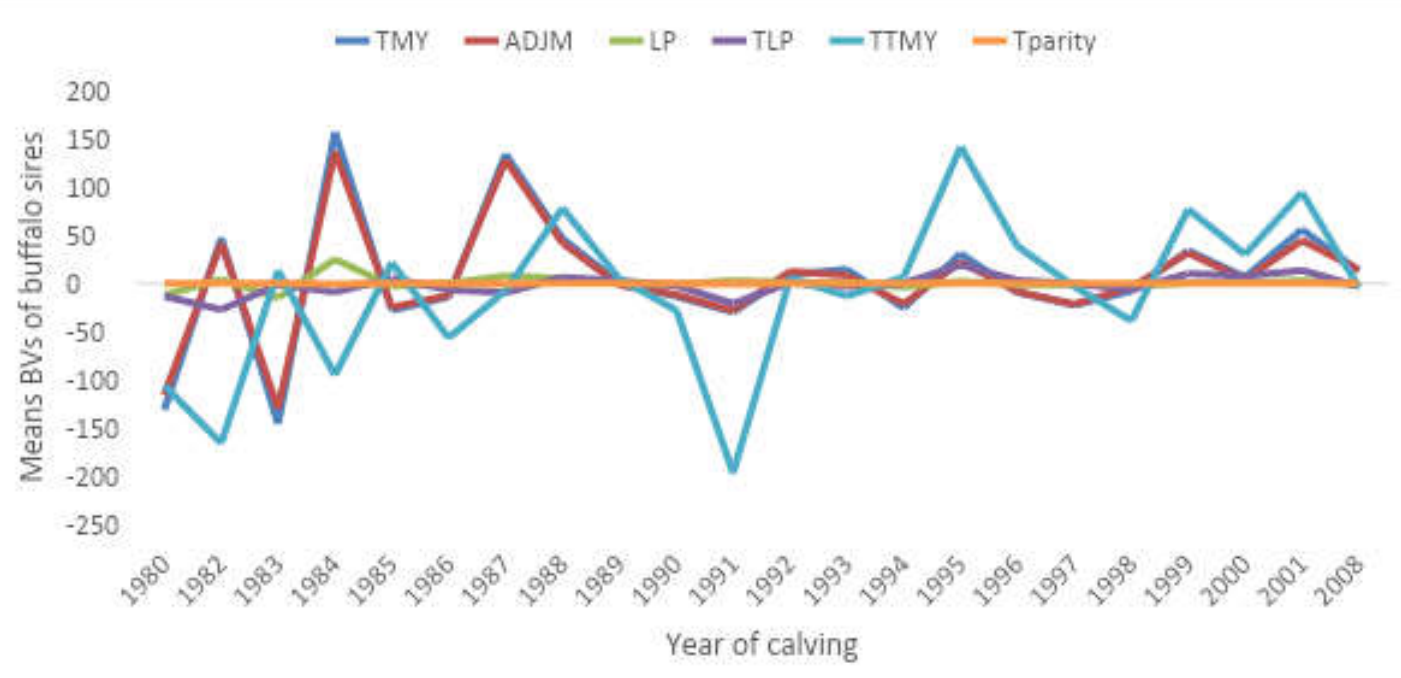

(c)

Figure 1: genetic trend of average breeding values (BVs) for buffalo cow (a), buffalo dam (b) and buffalo sire (c) for total milk yield (TMY), 305-day milk yield (ADJM), Lactation period (LP), Productive life (TLP), Total milk yield during the productive life (TTMY) and Number of lactation (T parity) in Egyptian buffalo.

\section{CONCLUSION}

The positive significance of genetic trend of animal and dam breeding value of the milk production and longevity traits indicates the possibility of carrying out the genetic improvement of these traits.

\section{REFERENCES}

Ahmed, M , 2016. Estimated breeding values and genetic trend for milk yield in Nili Ravi buffaloes. Italian Journal of Animal Science, 6: 393-396.

Arab Agricultural Statistics year book. 2017 Vol. 37http://www.aoad.org/ASSY37/statbook37Cont. htm

Amimo, J.O , J.W. Wakhungu, B.O. Inyangala and R.O. Mosi, 2007. The effects of non genetic factors and estimation of genetic and phenotypic parameter and trends for milk yield in Ayrshire cattle in Keneya. Livestock Res. Rural Development, 19(1):1-9.

Aziz, M.A , S.J. Schoeman, G.F. Jordaan, O.F. ElChafie, and A.T. Mahdy. 2001. Genetic and phenotypic variation of some reproductive traits in Egyptian buffalo. S.Afr.J.Anim.Sci., 31, 195198.

Bashir, M.K , M.S. Khan, S.A. Bhatti, and A. Iqbal. 2007. Lifetime performance of Nili-Ravi buffalo in Pakistan. Asian-Aust.J.Anim.Sci. 20 (5):661668.

Cady, R.A, S.K. Shah, L.C. Schemerrhorn, and R.E. McDowell .1983. Factors affecting performance or Nili-Ravi buffaloes in Pakistan. Journal of Dairy Science. 66; 578-586.
El- Baramony, M. and M. Manal 2014. Estimates of genetics and phenotypic parameters for milk yield, lactation length, calving interval and body weight in the first lactation of Egyptian buffalo. Life Science Journal 2014, 11 (12): 1012-1019.

Galeazzi, P.M , E.Z. Mercandante, J.A. Silva, G.M. de Albuquerul, F. de Camargo and H. Tonhati 2010. Analysis of culling probability in dairy buffalo using survival models. Animal (4): 13251329.

Herbert, S. and D.S. Bhatnagar 1988. Genetic trends of economic traits in dairy cattle. A review. Agric. Rev., 9:200-216

Jakhar,V, A.K. Vinayak and K.P. Singh. 2016. Genetic evaluation of performance attributes in Murrah buffaloes. Haryana Vet. 55(1): 66-69.

Khan, M.S. and H.Z. Chaudhry. 2001. Prediction of lactation yield from last record day and average daily yield in Nili-Ravi buffaloes. Buffalo Newsletter, 15: 7-10.

Khan, M.S , M. Faiz-Hassan, A.U. Hagder and L.R. Bajwa. 2007. Genetic control of milk yield lactation of different Duration in Nil-Ravi. Buffaloes Arch., Fuo Tierzuch. 50: 227-239.

Khattab, A.S , M. Shimmay, A. El-Komey, Kawther, A. Mourad and Abdel-Bary, Walaa. 2017. Genetic evaluation for lifetime production and longevity traits on Egyptian buffaloes. EAAP $68^{\text {th }}$ Annual Meeting Tallinn, Egypt.

Meyer, K. 2005. Ordering strategies to reduce computational requirements in variance component estimation. Proc Ass Advan Anim Breed Genet. 2005;16:282-285.

Morammazi, S.R, V. Torshizi, Y. Rouzbenh and Y. Syyardn. 2007. Estimation genetic parameters for production and reproduction traits in Khuzestan 
buffaloes. Proc., $8^{\text {th }}$ world buffaloes congress Caserta, Italy, 19-22 October, 2007.

Ojango, J.M. and G.E. Pollott 2001. Genetic of milk yield and fertility traits in Holstein-Friesian cattle on large-scale Kenyan farms. J. Anim. Sci.,79:1742-1750

Pareek, N.K. and R.Narang. 2014. Genetic analysis of first lactation persistency and milk production traits in graded Murrah buffaloes. Buffalo Bulletin, 33 (4): 432-436.

Peeva, T. and Y. Ilieva. 2007. Longevity of buffalo cows and reasons for their culling.Ital.J.Anim.Sci. vol. 6, (Suppl. 2), 378-380, 2007.

SAS. (2010). Statistical Analysis System, User's Guide Computers by SAS Institute Inc., Cary, $\mathrm{NC}$, USA.
Shah, S.N.H. 2007. Prolonged Calving Intervals in the Nili Ravi buffalo.Ital.J.Anim.Sci. vol. 6, (Suppl. 2), 694-696, 2007.

Thiruvenkadan, A.K , S. Paneerselvam and R. Rajendran. 2015. Lifetime performance of Murrah buffaloes hot and humid climate of Tamil Nadu. India Buffalo Bulletin. 34(1): 92-99.

Tonhati, H , M.F. Ceron-Munoz, A.J. Oliveira, J.M.C. Duarte, T.P. Furtado and S.P. Tseimazides. 2000. Genetic parameters of milk production, fat and protein contents in buffalo milk. Rev Bras Zootec. (29): 2051- 2056.

Zadeh, N.C. H. 2016. Estimates genetic parameters and genetic trends for production and reproduction traits in Iranian buffaloes. ESEARCH Article 8- 2016.

\footnotetext{
الاتجاه الوراثي لإنتاج الحليب وسمات طول العمر للجاموس المصري

داليا قاسم الحديني' ، خلود علي البنهاوي' ، امين محمد سيد امين' ، محمد محمود سالم' ، محمد حسن حمود' ، عادل سيد

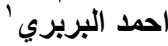

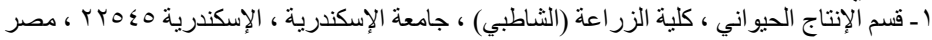

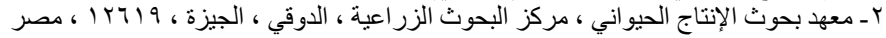

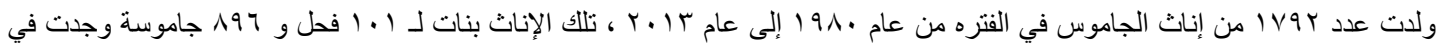

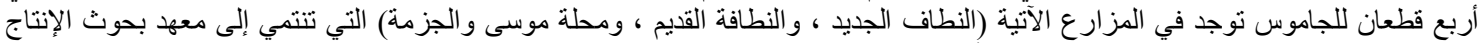

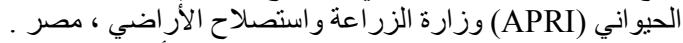

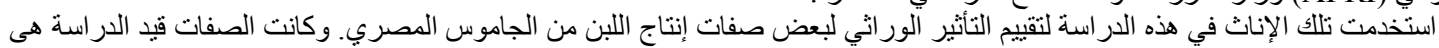

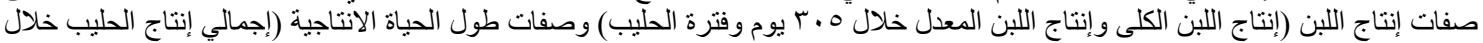

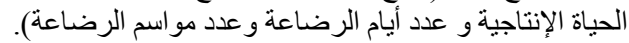

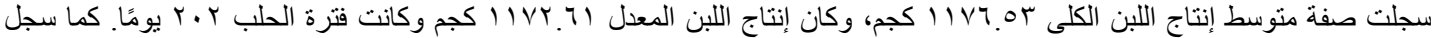

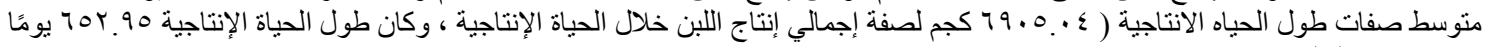

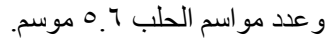

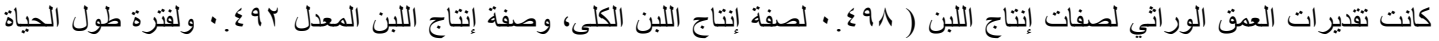

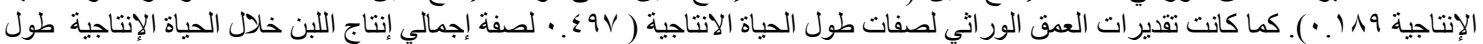

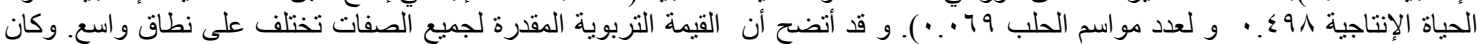

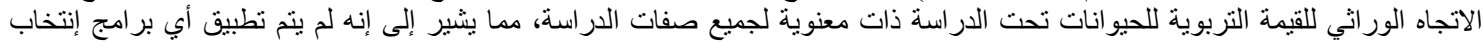
ور اثي لهذه الحيو انات.
} 